\title{
The face-to-face encounter in indigenous health care: a perspective in Lévinas
}

\author{
O encontro face a face no cuidado em saúde indígena: uma perspectiva em Lévinas \\ El encuentro frente a frente en el cuidado en la salud indígena: una perspectiva en Lévinas
}

\begin{abstract}
Diomedia Zacarias Teixeira', Nelson dos Santos Nunes',
Rose Mary Costa Rosa Andrade Silva', Eliane Ramos Pereira', Vilza Handan'
'Universidade Federal Fluminense, Aurora Nursing School of Affonso Costa. Niterói, Rio de Janeiro, Brazil.
How to cite this article:
Teixeira DZ, Nunes NS, Silva RMCRA, Pereira ER, Handan V. The face-to-face encounter in indigenous health care: a
perspective in Lévinas. Rev Bras Enferm [Internet]. 2018;71(Suppl 6):2848-53. [Thematic Issue: Good practices in the care
process as the centrality of the Nursing] DOI: http://dx.doi.org/10.1590/0034-7167-2017-0389
\end{abstract}
Submission: 06-05-2017

Approval: 10-04-2017

\begin{abstract}
Objective: To reflect on the sensitive behaviors of indigenous healthcare professionals based on the philosophy of Emmanuel Lévinas, to ratify completeness, equity, and humanity. Method: reflective study. Reflection: Studies have identified inadequacies in meeting the indigenous singularities. In the hospital and outpatient settings, they are diluted in the search for care. The difficulty of the professionals to admit them generates conflicts and non-adherence of indigenous individuals to treatments that disregard their care practices. In Lévinas, consciousness requires, "a priori," sensitivity to access the Infinity on the Face of the Other, which in the face-to-face encounters is presented to the Self as radical Alterity, proposing an Ethical relationship through transcendence. The freedom of the Self as to the Other is finite, as the Self cannot possess the Other, and infinite for its responsibility for the Other. Final considerations: The Self builds essence and existence in responsibility. In the Ethics of Alterity, in Lévinas, reflections are proposed that influence sensitive behaviors.
\end{abstract}

Descriptors: Health of Indigenous Populations; Nursing Care; Reception; Humanization of Care; Health Legislation.

\section{RESUMO}

Objetivo: Refletir sobre os comportamentos sensíveis dos profissionais em saúde indígena a partir da filosofia de Emmanuel Lévinas, para ratificar a integralidade, a equidade e a humanidade. Método: estudo reflexivo. Reflexão: Estudos têm identificado inadequações no atendimento às singularidades indígenas. Nos cenários hospitalar e ambulatorial, elas se diluem na busca por cuidados. A dificuldade dos profissionais em admiti-las gera conflitos e não adesão dos indígenas a tratamentos que desconsideram suas práticas de cuidado. Em Lévinas, a consciência requer,"a priori," sensibilidade para acessar o Infinito no Rosto do Outro, que nos encontros face a face se apresenta ao Eu como Alteridade radical, propondo uma relação Ética pela transcendência. A liberdade do Eu quanto ao Outro é finita, porque dele não pode se apossar, e infinita pela sua responsabilidade pelo Outro. Considerações finais: O Eu constrói essência e existência na responsabilidade. Na Ética da Alteridade, em Lévinas, propõem-se reflexões que influenciem comportamentos sensíveis. Descritores: Saúde de Populações Indígenas; Cuidados de Enfermagem; Acolhimento; Humanização da Assistência; Legislação Sanitária.

\section{RESUMEN}

Objetivo: Reflejar sobre los comportamientos sensibles de los profesionales en salud indígena desde la filosofía de Emmanuel Lévinas, para ratificar la integralidad, la equidad y la humanidad. Método: Estudio reflexivo. Reflejo: Estudios están identificando inadecuaciones en la atención a las singularidades indígenas. En los escenarios hospitalarios y de ambulatorios, ellas se diluyen en la búsqueda por cuidados. La dificultad de los profesionales en admitirlas genera conflictos y no aceptación de los indígenas a tratamientos que no consideran sus prácticas de cuidado. En Lévinas, la consciencia requiere, "a priori," sensibilidad para acceder el Infinito en el Rostro del Otro, que en los encuentros frente a frente se presenta al Yo como Alteridad radical, proponiendo una relación Ética por la transcendencia. La libertad del Yo cuanto al Otro es finita, porque de él no puede apropiarse, e infinita por su responsabilidad por el Otro. Consideraciones finales: El Yo construye la esencia y la existencia en la responsabilidad. En la Ética de la Alteridad, en Lévinas, se proponen reflejos que influencien los comportamientos sensibles. 
Descriptores: Salud de Poblaciones Indígenas; Cuidados de Enfermería; Acogida; Humanización de la Asistencia; Legislación Sanitaria.

\section{CORRESPONDING AUTHORＤiomedia Zacarias Teixeira E-mail: diomedia39@yahoo.com.br}

\section{INTRODUCTION}

Life, at the same time it demands, it provides us with encounters and exchanges. We are beings of relationships; we influence and are influenced by Others around us: the environment, the other beings with their ways of being and existing, their beliefs and values, their cultural system, their social organization, and their economic system.

We are beings within time frames of birth and death. Between these two times, we follow a path in which we build a story of life in a history of world, in which we incessantly seek to be steady and self-assured: we are historical and unfinished beings ${ }^{(1)}$. Meanwhile, we have a gregarious instinct, a fact that necessarily leads us to encounters in which we establish exchanges with others like us, which leads us to perceive something that we lack, to reflect on how incomplete and unfinished we are and to seek to fill this gap.

According to Emmanuel Lévinas, French-Lithuanian philosopher, critic of the Ontology and of the Self-in-oneself as mode of self-conception, the encounter with and the perception of the coexistence of Other(s) already imply the admissibility of a nonSelf, whose presence is imposed by the face in the face-to-face encounters and, at the same time that demands responsibility, cannot be encompassed and totaled by the Self ${ }^{(2)}$.

These encounters are occasions conducive to expression of subjectivities, to the recruitment of individual resources and of skills, which lead to action and establish an interaction.

One of the phenomena that emerge from these occasions is the care, both as self-care and as potentiality for care of others. Care is a behavior that stems from involvement, based on affectivity ${ }^{(3)}$.

Along the temporal and social-historical path, which serves as backdrop for us to build ourselves as human beings, we need to give care and receive care. However, care is not solely a necessity or an imposition of life, but can be understood as intrinsic to the existence, something that naturally exists before human beings do anything ${ }^{(3)}$. It is expressed as a way of relating to $^{(4)}$ the Other, but not always conforms comprising the ethical and aesthetic dimensions ${ }^{(4)}$ in this relationship with the Other.

Thus, it is appropriate to resort to the philosophical conceptions that support the reflection on the importance of the Other coexisting in the face-to-face encounters for the care. In a Heideggerian perspective, the care is a possibility of being. The being-in-itself (Dasein) is constituted as being-in-the-world, in perceiving other Daseins with the same capacity and in relating to the world around. As there is co-existence with the "Other Dasein," to whom one relates and with whom one shares the world, Dasein is converted into Mitsein, becoming a beingwith-others. Only in the Mitsein character a being encounters with Others in a shared world ${ }^{(5)}$.

As Buber posits the concepts of relation (expressed in the "IThou") and of relationship (expressed in the "I-It") $)^{(6)}$, Heidegger conceives the distinction between occupation (the encounter of a being with other innerworldly beings) and preoccupation (relationship between beings with the same attributes). It is in the preoccupation that Dasein is expressed as being-with-others. Thus, the preoccupation is translated as care of the being-withothers and therefore of the being-in-itself. By taking from it the care, it is deprived of the possibility of being ${ }^{(5)}$.

In a comparison of the conceptions in question, the imposition of the Face in the face-to-face encounters requires care and instigates the Self to come out of itself. In Lévinas, this essential movement for care is consistent with the concepts of relation in Buber and of preoccupation in Heidegger, founded much more on Ethics as prior philosophy, before and from the presence of the Other, than on the attitude of encounter, reciprocity, and mutual confirmation (relation) or even of care of the beingwith-others (preoccupation) as indispensable movement for the affirmation of the being-in-itself.

If it is true that in the large cities of our country we coexist with inequalities of diverse natures and with the radical diversity of formation of their people, in the context of the Brazilian Legal Amazon that is equally or more true, especially regarding the indigenous peoples and their multi-ethnic and multicultural contexts, that configure the coexistence with Others and their different modes of being in a world-of-life, with their conceptions of health and illness, their values, their beliefs, their practices of prevention, treatment and cure, providing the environment for the dawn of Alterities.

In this context, basing the professional practices on an epistemology of health constitutes a resource of value, since, from the interface of the biomedical models and of the traditional indigenous medicine, emerge multiple and distinct, individual and collective, multifaceted concepts of health and disease, which necessarily will have to dialogue according to their levels of complexity and to the various emergency plans involved ${ }^{(7)}$.

Lévinas, based on the understanding of the world-of-life and of the Other, proposes the recovery of humanism as a guide for human relationships, founded on the Ethics of Alterity. The other, a non-Self, eludes understanding, imposes itself through the richness of content, as well as through the absence of meanings ${ }^{(8)}$, constituting a challenge with the Face, the barest part of the body of the Other, which not only concentrates the totality of its senses, but that presents itself expressing feelings or not.

According to Lévinas, the manifestation of the Other pervades the shape and contours of the Face and is configured in a first discourse, even before speech ${ }^{(2)}$. It is in the exposure of the Face and in the absence of discourse that the face-to-face encounter acquires meaning ${ }^{(2)}$, since it challenges the Self to come out of itself in search of an understanding that will never be accomplished, that questions the Self in everything, and that leads it to an emptying of itself $f^{(2)}$.

The Face of the Other in the face-to-face encounters, while appealing for Alterity, demands responsibility, in view of the 
initial challenge and of the consequent movement of the Self towards the Other. The responsibility of this Self, a response to the appeal of the Other through the Face, subordinates its freedom.

Thus, in subordinating freedom to responsibility ${ }^{(9)}$, the Self builds its mode of being and existing, structured in an Ethics of Alterity. Consequently, it builds its freedom molded to this ethics, thus configuring a distinct way of relating to the world and to the Others. Thus, it restores the humanism, in whose context its freedom leads it to justice.

Despite the advances observed with the creation of the Subsystem of Indigenous Health and of the National Policy for Health Care of Indigenous Peoples (PNASPI)(10), in the context of the Rio Negro region, in the northwestern part of the state of Amazonas - a region of the country that is home to numerous indigenous peoples -, there is still much to be implemented to ratify the Basic Principles of Completeness and Equity, specifically regarding the relationships between health professionals and indigenous users of the various ethnic groups.

In the daily routine of care in the hospital and health centers in that region, the relations and interventions of the non-indigenous healthcare professionals follow a compartmentalizing model of care that excludes alterity, denoting, without much effort, the lack of training and the unpreparedness of these professionals to work in contexts of multiethnicity and interculturality, especially with indigenous populations.

On the other hand, indigenous healthcare professionals from the region, who work and reside in the main city of the municipality, are not majority when compared with the group of non-indigenous professionals; however, despite this and the fact that they incorporated the professional practices of the model in force, they still retain, totally or partially, traditional knowledge of the ethnicity to which they belong and even knowledge of other ethnicities in the region, such compliance being a potential positive factor for the implementation of attitudes that foster integration and equity.

Thus, we have the following guiding question: How the behavior of healthcare professionals may be influenced by a philosophy, for the achievement of a complete, fair, and humanized care, in the multiethnic and multicultural contexts of indigenous health care?

Considering that philosophical-theoretical assumptions support the conception and implementation of care, our objective is to reflect, based on the philosophy of Emmanuel Lévinas, on sensitive behaviors of professionals working on indigenous health care, as a means of ratifying the completeness, equity, and humaneness in health care.

As to the implementation of care in encounters between healthcare professionals and users, it is essential to reflect on concepts and practices involved in the relation between technical and humanistic aspects ${ }^{(11)}$.

Immediately, it should be highlighted the attitude of man before the world: that of relation, present in the concept of "I-Thou," in the reciprocity between partners; and that of relationship, present in the I-It, in which the being faces an object and is constituted in a subject of knowledge. In the relation through dialogue, the Self and the Thou are respectively present as person and as the other. The responsibility for this other is present both in Buber's philosophy, through the transcendent self-contemplation, which refers to selflessness and overcoming of selfishness, and in Lévinas' philosophy, through the Ethics that shows itself before the primordial presence and dialogue, non-verbal, established in the face-to-face encounters ${ }^{(2-6)}$.

In spite of the scientific-technological evolution in the field of health and the resources generated by it, their application should be invested with meaning and reflect importance for the life project of health professionals and users ${ }^{(11)}$.

The theme is justified primarily because the author is indigenous and has lived the advances and setbacks in the process of construction of the Brazilian Unified Health System (SUS), which occurred and still occurs under various influences, affected by multiple interests and characterized by regional, cultural, social, and economic inequalities. The experience began in childhood and early adolescence in the countryside of the state of Amazonas, when, in seeking health services, encountered the difficulties of access to the completion of the service. It extended through adulthood, as a nurse specializing in indigenous health, providing care and facing other obstacles and challenges. Therefore, two approaches about problems encountered experiencing both sides of the healthcare system, considering the time they occurred, the geographical space, and the other influencing factors.

It is also justified by the value and significance of the principles of Universality, Completeness, and Equity of the SUS, which have mobilized civil society to demand from the public authorities the development, proposal, and implementation of policies that meet the needs of the national population for health services in all degrees of complexity; as well as provide and facilitate accessibility especially for those considered vulnerable and/or that require differentiated care: indigenous peoples, women, disabled individuals, older adults, children, adolescents, lesbians, gays, bisexuals, and transgender people.

The relevance of this subject is due to the fact that the health of indigenous peoples is a subtheme of the National Agenda of Priorities in Health Research, specifically regarding the item "1.1.4 - Research of the sociocultural practices related to selfcare in health in a broad sense (social and physical reproduction of the community) and, in the strict sense, of the practices related to the health-disease process," and to its sub-items "1.1.4.1 - Studies on forms of sociopolitical organization of the indigenous peoples and their interfaces with health" and "1.1.4.2 - Research on indigenous health systems, self-care and indigenous healing practices, with emphasis on the context of epidemiological transition"(12); the theme is also relevant because the care practices at the various levels of complexity require adjustments to comply with the provisions of the National Policy for Indigenous Health Care ${ }^{(10)}$.

\section{REFLECTION}

The National Policy for Indigenous Health Care ${ }^{(10)}$, when addressing the training of human resources for work in indigenous contexts, recommends that health workers are trained, qualified, and appropriate the resources and techniques of the 
biomedical model in force, in order to incorporate them to the therapeutic arsenal of the traditional indigenous culture and medicine. It also recommends that the SUS provides courses for its professionals in the various spheres of activity, in order to train them to work in the different settings of indigenous health.

The health workers, residents of indigenous communities, are trained to work locally based on the biomedical model in force and are part of the Multidisciplinary Team in Indigenous Health (EMSI). Therefore, they have a set of knowledge and practices that they disseminate and apply in those communities, under guidance and supervision of the other members of the EMSI - physician, nurse, dentist, and nursing technician.

Thus, such knowledge and practices reach distinct populations in remote locations and are eventually incorporated into the daily routine of local health production, coming to coexist as complementary resources to the knowledge and practices of traditional indigenous medicine.

The active search for detection of prevalent diseases, the collection of material for examination, and the use of medicines from the pharmaceutical industry - easily usable and whose beneficial effects are often felt within a short period, to such extent that they come to do without rites and practices of traditional medicine that require a longer time - are usual resources from the biomedical model incorporated into many indigenous communities, to the point that it is observed that they have become resources of first election in the treatment of physical ailments.

On the other hand, indigenous peoples conceive some other ailments, for which the resources of the biomedical model do not apply: they are "indigenous people's diseases," which involve knowledge and interventions of shamans, root/herb healers, and spiritual healers, specialists of traditional indigenous medicine. In many communities, the resources and practices of traditional medicine are still the most prevalent, which those specialists employ to promote health, treat diseases, and heal them.

The conceptions of health and illness emerge from their own way of being and existing - built based on the culture and society of a people - and are associated with an identity and affirm an Alterity.

While knowledge and practices of the biomedical model are mixed with those of traditional medicine in indigenous communities - coexisting at times as complementary resource, at times as main resource to be used in the prevention, treatment, and cure - in environments of hospitals and basic health units the knowledge and practices of the biomedical model are still the most prevalent.

Despite the recommendations of the National Policy for Indigenous Health Care ${ }^{(10)}$, non-indigenous health care professionals who already work in those environments, and even those who are hired to work there, usually do not receive any training for social interaction with indigenous peoples in the context of multiethnicity and interculturality. The training courses and adaptations, when promoted for the work with these populations, prioritize technical issues of practical application in health actions, while philosophical-theoretical conceptual aspects are at times deemed as secondary and cited without much further study and at other times not even that occurs.
However, it should be considered that the health promotion practices and the illness process are complex phenomena that involve multiple variables and that the care required in these cases also acquire a complex character, in which singularities appear and need to be considered in the individual, family, and collective spheres in the indigenous context in the state of Amazonas, Brazil.

Much has been identified in studies produced in the country about the lack of awareness of the non-indigenous healthcare professionals about the indigenous social-economic organization, production of knowledge, culture, and medicine ${ }^{(11)}$, especially in the health services of higher complexity ${ }^{(13)}$, in which addressing the singularities translates both as impertinent to the prevalent biomedical model and as questioning of its capacity to meet all the needs for health. In short, it eventually exposes the limitations of this model. Such situations often ratify the inequality and the invisibility of individuals seeking health care, as their singularities become diluted in cases, numbers, indices, and statistics ${ }^{(14)}$.

Indigenous practices and knowledge cultivated by their ancestors and transmitted to succeeding generations, which originate in the world of life and express distinct perspectives, have no space in these situations. That is due to the reliance of professionals working in the hospital and health clinics on scientific objectivity, as such reliance leaves no room for the aesthetic dimension of care, since it requires the development of sensitivity, availability, and flexibility to understand other logics that are not supported by science and reason, but that at the same time have their own rationales and are no less true within a logic that is distinct from scientific logic. Most of the time, the reliance on scientific objectivity stems from the structure of the difficulty that health professionals have to understand the expression of those perspectives and that often results in conflicts with indigenous users ${ }^{(11-13)}$.

Health professionals should, then, transcend in their relationships with users ${ }^{(13)}$; they should go beyond the biological body, seeking to understand different conceptions of health and illness, of prevention, treatment, and cure ${ }^{(13)}$.

The therapeutic approaches and interventions based on the conceptions of health and illness of the Other, reflecting meaning and significance for the users' individual and collective projects of life, bring the character of challenge and innovation for health professionals, especially regarding the conception and implementation of care from the perspective of nurses and nursing technicians.

A care whose development is based on reason, guided by established epidemiological-clinical and technical evidence concerning therapeutic intervention, is indispensable. However, it is necessary to create space to integrate indigenous knowledge and practices of health promotion, disease prevention and treatment, and healing practices, since, in order to meet the needs and specificities of a differentiated population group, each knowledge should not be more prevalent than the other, since both are complementary.

Notwithstanding the transcendence of health professionals, what is observed in the daily care of hospital and basic health units is a difficulty of adaptation of indigenous users, especially when this user requires hospitalization for an extended period ${ }^{(13)}$. 
Under these conditions, the discontent of indigenous individuals in feeling the weight of a prescriptive treatment under hospitalization, which limits their freedom to roam and act and does not consider cultural practices of self-care, signified and founded on the participation of their community and family, ultimately results in their non-adherence to the guidelines and treatments provided ${ }^{(11)}$ and translates as hospital evasion and therapy abandonment.

However, the everyday routine of reception and care in the settings of hospitals and basic health units should be considered as the most suitable occasions to exercise ethics, since the encounter of Self-Other is the encounter of Subjectivity with Alterity ${ }^{(8)}$.

It is true that philosophy propounds thinking and discussing human questions and concerns on various conceptions, irrespective of the time and place where they live. Trivial aspects that pervade the everyday life and that mark the singularity of a person or group are far from being examined by health professionals. These issues require reflections of these professionals about their care practices, without reducing the Other to an object $^{(8)}$ or extinguish their singularity ${ }^{(9)}$.

Implementing health actions in indigenous multiethnic and multicultural contexts requires that professionals are willing to work out the admission of different forms of thinking and conducting oneself in life; developing their sensitivity beyond what can be apprehended by the senses ${ }^{(9)}$ in the encounter with the Other.

Lévinas argues that the meaning is a priori, that is, it will always come before the "understanding as"(9). If being aware of something or someone refers to the manner how both are "understood as," then, in Lévinas' assumption, before having awareness it is necessary to have developed the sensitivity ${ }^{(9)}$.

The sensitivity to admit as legitimate, for example, the conduct and decision of indigenous parents before the agony and death of their young daughter, despite the expressed disbelief of some professionals due to those parents' non-authorization of intense and effective clinical interventions, far beyond the support and comfort measures put in place. These, aside from the relief provided at that time, could reverse an adverse condition to life and maybe enable a cure. The parents conceived that the suffering of the young daughter would be due to the breach of protection rites, condition that, in that case, would lead to a fatal outcome expected for the young girl. However, they were comforted because they knew that long before they had obtained the healing of the spirit of the indigenous youth through the representatives of indigenous medicine and that, despite that agony and death, her spirit was safe. The parents were certain and assured of their conceptions.

In the context of indigenous health actions, beyond thinking based on a prevalent biomedical model, it is necessary to develop the sensitivity to give meaning to something based on other ways of conceiving life, world, and everything, because an Other presents itself to the Self as radical Alterity ${ }^{(9)}$, which imposes itself and is not exhausted before the Self's attempt at understanding and totalizing it.

Through a referential model of domination, the non-indigenous totalizing Self comes to signify the indigenous Alterity and its indissociable insubmission through attributes such as primitivism, ignorance, and laziness. The development of the sensitivity to admit different modes of life that are not submitted to the totalization through understanding becomes essential for the immersion into Lévinas' concept of infinity.

The indigenous multiethnicity and interculturality configure multiple Faces and, consequently, multiple Alterities. The Alterity, basic concept of Lévinas, is expressed through the Face, which is configured as the first language, the first discourse before the dialogue, the initial moment in which the Other is revealed to the Self; therefore, it can be inferred that, in the context of indigenous health care, the face-to-face encounters that take place are intense, in part because of the multiplicity of different Faces, that harmonize "with" and "in" the Amazonian diversity and that ultimately define its characteristic.

From these encounters, for example, emerge both the human capacity to adapt to live and survive in environments that are hostile toward life and the need for health care resulting from this adaptation. The capacity for adaptation (potentiality for life) and the need for health (limitation to life) can serve as an invitation to lead health professionals to reflect on how they are opposites that coexist because they are inherent in life; similarly, Subjectivity and Alterity are opposites that also coexist because they are part of life, but that can enable a path toward humanization, as the Self (Subjectivity) comes out of itself toward an Other (Alterity) that presents itself as Infinity ${ }^{(8)}$, for it can never be totaled through understanding.

In the totalizing perspective, the Self-in-itself seeks to totalize the indigenous Other through understanding, based on the exotic stereotype of this Other, whose beliefs and knowledge have no scientific basis and whose health problems result from habits that require self-care and care from peers and toward peers.

This Other needs to assimilate, in a short period, the care conceived by the professional, as if it were possible to discard, in an instant, knowledge and practices assimilated for generations and at the same time replace them with new conceptions in biomedical bases. The abandonment of treatment results from such aspect, which ultimately reinforces the inequities.

In the perspective of sensitivity to Alterity, the Other is proposed to the Self in a relationship of ethics, demanding transcendence. In this mode of relationship, family members of some indigenous patient and leaders of the respective community are invited to participate in discussions and decisions about the therapeutic conducts that consider their beliefs and values. The decision-making process is then shared and respected, no longer conducted only by the health care professional. The professional's freedom, in this case, is finite, fair, and human: fair because finite, as it is human because fair.

The demands of the Other, based on their issues and needs, will determine the freedom of the Self. In this logic, the responses provided by the Other subordinate the freedom of the Self to the responsibility, that is, regulate its freedom based on the responsibility that they now have.

Considering that the Face shows the infinitude of the Other, as this cannot be conceptualized and totalized by the Self, limiting its freedom; that if the Other is Infinity, then the responsibility of the Self toward the Other is also infinite; that If the issues and needs of that Other determine the responsibility of the Self, then these are also infinite, as they refer to the infinity of the Other; 
that although the responsibility of the Self is infinite because of the infinitude of the Other, its freedom is not, because, to be fair, it has to be finite; therefore, if the responsibility of the Self toward the Other is infinite, because it needs to respond infinitely to the issues and needs of the Other, and its freedom is finite to be fair, would not there be an imbalance or even an injustice, that is, should not the freedom of the Self also be infinite?

However, the freedom of the Self is finite in relation to the Other, because this is not something that the Self can possess. In the sense of search of answers due to the infinite responsibility of the Self toward the Other ${ }^{(8)}$, freedom can be understood as infinite.

\section{FINAL CONSIDERATIONS}

This movement of coming out of the Self-in-itself toward the Other, created through a responsibility toward this Other, configures the Ethics of Alterity. It is based on the Other and on the responsibility required by it that the Self constructs its essence and its existence. This movement of coming out of oneself, based on the responsibility toward the Other, with the freedom to seek answers to the issues and needs evoked by it, goes beyond that construction, as in being a practice that requires justice, in the context of indigenous health, it can be translated as seeking to achieve the completeness and equity and the ratification of the humanization practices included in the health sector policies.

Therefore, the Ethics of Alterity, founded on the philosophy of Emmanuel Lévinas, is the framework based on which reflections may be proposed that may influence the change of behaviors of health professionals, whose care actions in indigenous multiethnic and multicultural contexts go beyond the limitation of the technical-scientific aspect.

\section{REFERENCES}

1. Freire P. Pedagogia da autonomia: saberes necessários à prática educativa. São Paulo: Paz e Terra; 1996.

2. Lévinas E. O humanismo do outro homem. 4ª ed. Petrópolis: Vozes; 2012.

3. Boff L. Saber cuidar: ética do humano - compaixão pela terra. Petrópolis: Vozes; 1999.

4. Waldow VR. Cuidado humano: o resgate necessário. Porto Alegre: Sagra-Luzzatto; 2001.

5. Heidegger M. Ser e Tempo: parte I. 15ª ed. Petrópolis: Vozes; 2005.

6. Buber M. Eu e Tu. 10 ed. São Paulo: Centauro Ed; 2001.

7. Almeida Filho N. Epistemologia da saúde: do problema de Kant-Gadamer à teoria dos modos de saúde[Internet]. In: Almeida Filho N, (Org.). Teorias de saúde-doença: estudos sobre conceitos de saúde, doença, cuidado, risco (e correlatos). 2011 [cited 2017 Sep 5]. Available from: http://teorias-saude-doenca.blogspot.com.br/p/sumario-da-coletanea.html

8. Almeida DV, Ribeiro Jr N. A sensibilidade e a humanização dos cuidados em saúde a partir da relação ética com o rosto do outro. Mun Saúde[Internet]. 2012[cited 2017 Sep 5];36(3):407-15. Available from: http://bvsms.saude.gov.br/bvs/artigos/mundo_saude/ sensibilidade_humanizacao_cuidados_saude_partir.pdf

9. Almeida DV. A filosofia levinasiana numa experiência de cuidar em enfermagem: a humanização decorrente da alteridade. Rev Enf Ref[Internet]. 2013[cited 2017 Sep 5];3(9):171-9. Available from: http://www.redalyc.org/articulo.oa?id=388239968001

10. Brasil. Ministério da Saúde. Fundação Nacional de Saúde. Política Nacional de Atenção à Saúde dos Povos Indígenas. $2^{a}$ edição. Brasília: Fundação Nacional de Saúde; 2002.

11. Ayres JRCM. Desenvolvimento histórico-epistemológico da Epidemiologia e do conceito de risco. Cad. Saúde Pública[Internet]. 2011[cited 2017 Sep 5];27(7):1301-11. Available from: http://www.scielo.br/pdf/csp/v27n7/06.pdf

12. Brasil. Ministério da Saúde. Secretaria de Ciência. Tecnologia e Insumos Estratégicos. Departamento de Ciência e Tecnologia. Agenda nacional de prioridades de pesquisa em saúde. 2a ed. Brasília: Ministério da Saúde; 2015.

13. Pontes ALM, Garnelo L, Rego S. Reflexões sobre questões morais na relação de indígenas com os serviços de saúde. Rev Bioét[Internet]. 2014[cited 2017 Sep 5];22(2):337-46. Available from: http://revistabioetica.cfm.org.br/index.php/revista_bioetica/article/view/867

14. Pereira ER, Biruel EP, Oliveira LSS, Rodrigues DA. A experiência de um serviço de saúde especializado no atendimento a pacientes indígenas. Saúde Soc[Internet]. 2014[cited 2017 Sep 5];23(3):1077-90. Available from: http://www.scielo.br/pdf/sausoc/v23n3/01041290-sausoc-23-3-1077.pdf 